\title{
HELMINTHES OF MOUSE-LIKE RODENTS IN THE BELOGORYE STATE NATURE RESERVE (RUSSIA)
}

\author{
Margarita I. Kononova, Yuri A. Prisniy \\ Belgorod National Research University, Russia \\ e-mail:margosha.ki@yandex.ru,prisniy_y@bsu.edu.ru
}

Received: 04.04.2019. Revised: 21.04.2020. Accepted: 26.05.2020.

\begin{abstract}
The study was conducted in 2016-2017 on three sites in the Belogorye State Nature Reserve (Russia) located in the forest-steppe zone. These sites are 1) «Les na Vorskle», upland oak (Quercus robur) forest; 2) «Ostrasyevy Yary», ravine oak forest, grass-meadow steppe; 3) «Yamskaya Step'», Sury valley, shrublands and forb meadow steppe, Eremkin Log valley, upland oak forest, forb meadow steppe. The small mammals investigated in this present parasitological study were caught using snap traps. These traps were established in lines of 50 or 100 traps per line. In addition, single traps and cone-shape pitfall traps (average length of $30 \mathrm{~m}$ ) were used. The caught rodents (118 specimens) concern five species: Myodes glareolus, Microtus arvalis, Sylvaemus flavicollis, Sylvaemus uralensis, and Apodemus agrarius. The total prevalence by helminthes was $72 \%$. About $91 \%$ of the Muridae animals were infected, while the prevalence of infestation was $55.6 \%$ among the Cricetidae specimens. We registered 20 helminth taxa belonging to three classes, six orders, and 12 families. Among the trematodes only eurixenous species were found. Among the cestodes, eurixenous species predominated. Among the nematodes, eurixenous and stenoxenous species were present in almost equal proportion. Dominant species are characterised by maximal values of prevalence of infestation. There were Hymenolepis sp. (17\%) among Plathelminthes, species of Syphacia (35.6\%) and Heligmosomoides (27.1\%) among Nematoda, including Syphacia stroma (17\%) and Heligmosomoides polygyrus $(14.4 \%)$. The other helminth species registered in the present study were either small in number (with prevalence of invasion from $2 \%$ to $14 \%$ ) or rare (with prevalence of invasion less than $2 \%$ ). Platynosomum muris (Trematoda, Dicrocoeliidae) and Pterothominx sadovskoi (Nematoda, Capillariidae) were reported for the first time in the Central Chernozem Region of Russia.
\end{abstract}

Key words: Belgorod region, Cestoda, field vole, helminthes, mice, micromammals, Nematoda, parasites, Trematoda

\section{Introduction}

The biodiversity studies of certain taxonomic groups are one of the most important issues of environmental research. Environmental monitoring of particular areas without the knowledge of its flora and fauna is almost impossible. In natural ecosystems, parasitism is considered as an ecological phenomenon, the form of interspecific relationships. So the parasites having various ecological connections are a significant factor in the regulation of the functioning of the entire ecosystem (Romashova, 2004; Hudson et al., 2006).

Mouse-like rodents are one of the leading vertebrate groups in regard to the abundance and species diversity in the forest and forest-steppe ecosystems (Poulin \& Morand, 2000; Orlova \& Orlov, 2019). Being the consumers of the first and second orders in the food chains, the rodents play a significant role in the helminthes' circulation as intermediate and definitive hosts. They participate in the maintenance of natural focal infections and invasions (Summers et al., 2003).

The study of the helminthes of mouse-like rodents is of particular interest in Protected Ar- eas (PAs), where the zonal diversity of locally typical species and the conditions of their natural habitat are better preserved (Dobson et al., 2008; Sheykina \& Zhigileva, 2018). The Belogorye State Nature Reserve is one of the main PAs in the Belgorod region (European Russia).

The paper aims to study the helminth species composition in mouse-like rodents in the Belogorye State Nature Reserve. As previously there were no helminthological studies of small mammals in the Belgorod region, it is relevant to obtain information on the helminthes species composition in the Belogorye State Nature Reserve as one of the inventory stages assessing the natural resources of the Belgorod region.

\section{Material and Methods}

To conduct the parasitological study, small mammals were caught using snap traps with treadle (Karaseva \& Telitsina, 1996) during the spring - autumn of 2016-2017 on the sampling sites located in several clusters of the Belogorye State Nature Reserve. The first of them is «Les na Vorskle» (upland oak (Quercus robur 
L.) forest, $\left.50.612103^{\circ} \mathrm{N}, 35.994553^{\circ} \mathrm{E}\right)$. The second site is the "Ostrasyevy Yary» (ravine oak forest and forb meadow steppe, $50.553843^{\circ} \mathrm{N}$, $\left.36.054914^{\circ} \mathrm{E}\right)$. The third site is the «Yamskaya Step'» (Sury valley: shrublands and forb meadow steppe, $51.199722^{\circ} \mathrm{N}, 37.642222^{\circ} \mathrm{E}$; Eremkin Log valley: upland oak forest, forb meadow steppe, $51.177222^{\circ} \mathrm{N}, 37.650556^{\circ} \mathrm{E}$ ).

Snap traps were arranged in lines of 50 or 100 traps each. Additionally, single snap traps were used, too. We checked the traps every $24 \mathrm{~h}$. On the site "Ostrasyevy Yary», we used an additional catching method using cone-shape pitfall traps (average length $30 \mathrm{~m}$ ) (Karaseva \& Telitsina, 1996). In total, 312 snap-trap-days and 30 pitfall-trap-days were performed.

A total of 118 specimens of mouse-like rodents, belonging to five species, were captured: Myodes glareolus (Schreber, 1780) (53 specimens), Microtus arvalis (Pallas, 1778) (10 specimens), Sylvaemus flavicollis (Melchior, 1834) (38 specimens), Sylvaemus uralensis (Pallas, 1811) (15 specimens), and Apodemus agrarius (Pallas, 1771) (2 specimens). To determine the species of these small mammals, we used taxonomic keys according to Gromov \& Erbaeva (1995). The rodent taxonomy was used in accordance to Pavlinov \& Lissovsky (2012).

The helminthes detected during the autopsy were fixed, labeled, and delivered to the laboratory for subsequent staining and species determination (Anikanova et al., 2007). A total of 1813 helminthes were collected and analysed.

The helminth species were determined using taxonomic keys (Skryabin et al., 1961; Ryzhikov, 1978, 1979) and relevant publications (Romashova, 2004; Souza et al., 2009). The systematics of cestodes is used according to Caira et al. (2020).

Quantitative indicators of invasion and helminth occurrence in the hosts were evaluated. We used parasite prevalence $(P P)$, invasion in- tensity amplitude (IIA), and abundance index (AI) (Anikanova et al., 2007).

\section{Results and Discussion}

As a result, 1507 helminth specimens were determined down to species level, 302 specimens to genus level, and four specimens to family level. The helminthes have been found in 85 specimens $(72 \%)$ of mouse-like rodents belonging to five species. The $P P$ of Muridae species was $91 \%$, exceeding almost twofold the $P P$ of Cricetidae (55.6\%) (Table 1). We registered 20 helminth taxa belonging to three classes, six orders, and 12 families. Fourteen taxa have been identified to species level, four to genus level, and two taxa to family level. Seventeen species represent mature adults, three species larval stages (Table 2). The PP, IIA, and $A I$ indices of the found helminth species and their affiliation to a particular group by the method of infection of the hosts are presented in Table 3.

There was no apparent dominance of a particular rodent species. The highest occurrence was found for Myodes glareolus (45\%) and Sylvaemus flavicollis (32\%). These species dominated in the forest-steppe zone together with $S$. uralensis, although the last species occurs non-frequently in the samples $(13 \%)$. The occurrence frequency of these species gradually decreased at the boundary zones between forests and completely deforested areas (Vlasov, 1996). Microtus arvalis occurs relatively rarely $(8 \%)$ only at the open (woodless) areas in the site "Ostrasyevy Yary». Non-numerous records of Apodemus agrarius within the present study are in accordance with data of the last seven years that this species has been rarely recorded in the Belogorye State Nature Reserve. It is caused by unfavourable habitat conditions of ravine oak forests for this species (Vlasov, 1996; Shchekalo, 2017).

Table 1. The species composition of the mouse-like rodents and data on their invasion by helminthes in the Belogorye State Nature Reserve (European Russia) in 2016-2017

\begin{tabular}{|l|c|c|c|c|c|c|c|}
\hline \multirow{2}{*}{ Host species } & \multirow{2}{*}{$\begin{array}{c}\text { Number of } \\
\text { host specimens studied }\end{array}$} & \multirow{2}{*}{$P P, \%$} & \multicolumn{3}{c|}{ Number of helminth species } & \multicolumn{2}{c|}{$\begin{array}{c}\text { Number of } \\
\text { helminth specimens }\end{array}$} \\
\cline { 5 - 9 } & & & Trematoda & Cestoda & Nematoda & Total & 910 \\
\hline Myodes glareolus & 53 & 54.7 & 1 & 5 & 4 & 10 & 30 \\
\hline Microtus arvalis & 10 & 60.0 & - & 1 & 2 & 3 & 740 \\
\hline Sylvaemus flavicollis & 38 & 97.4 & 1 & 3 & 3 & 7 & 57 \\
\hline Sylvaemus uralensis & 15 & 73.3 & - & 2 & 2 & 4 & 76 \\
\hline Total & 2 & - & - & 1 & - & 1 & 25 \\
\hline
\end{tabular}


Table 2. The helminth species of mouse-like rodents in the Belogorye State Nature Reserve (European Russia) in 2016-2017

\begin{tabular}{|c|c|c|c|c|c|}
\hline № & Helminth taxa & Sites & Host & Localisation & $\begin{array}{l}\text { Specificity of } \\
\text { helminthes }\end{array}$ \\
\hline \multicolumn{6}{|c|}{ Trematoda } \\
\hline \multicolumn{6}{|c|}{ Family Dicrocoeliidae } \\
\hline 1 & Platynosomum muris Stcherbakova, 1942 & YS (Sv, ELv) & Myodes glareolus, Sylvaemus flavicollis & Liver & Euryxenous \\
\hline 2 & Dicrocoeliidae spp. Odhner, 1911 & YS (Sv, ELv) & Myodes glareolus, Sylvaemus flavicollis & Small intestine & Euryxenous \\
\hline \multicolumn{6}{|c|}{ Cestoda } \\
\hline \multicolumn{6}{|c|}{ Family Anoplocephalidae } \\
\hline 3 & $\begin{array}{l}\text { Anoplocephaloides dentata (Galli-Valerio, 1905) } \\
\text { Rausch, } 1976\end{array}$ & $\mathrm{OY}$ & Microtus arvalis & Small intestine & Euryxenous \\
\hline 4 & $\begin{array}{l}\text { Paranoplocephala omphalodes (Hermann, 1783) } \\
\text { Lühe, } 1910\end{array}$ & OY & Myodes glareolus & Small intestine & Oligoxenous \\
\hline \multicolumn{6}{|c|}{ Family Catenotaeniidae } \\
\hline 5 & $\begin{array}{l}\text { Catenotaenia henttoneni Haukisalmi \& Tenora, } \\
1993\end{array}$ & YS (Sv, ELv) & Myodes glareolus & Small intestine & Euryxenous \\
\hline 6 & Spasskijela lobata (Baer, 1925) Tenora, 1959 & OY, YS (ELv) & Sylvaemus flavicollis, Sylvaemus uralensis & Small intestine & Stenoxenous \\
\hline \multicolumn{6}{|c|}{ Family Hymenolepididae } \\
\hline 7 & Hymenolepis sp. & $\begin{array}{l}\text { LnV, OY, YS } \\
(\mathrm{Sv})\end{array}$ & $\begin{array}{l}\text { Myodes glareolus, Sylvaemus flavicollis, } \\
\text { Sylvaemus uralensis, Apodemus agrarius }\end{array}$ & Small intestine & Euryxenous \\
\hline \multicolumn{6}{|c|}{ Family Taeniidae } \\
\hline 8 & Taenia sp. L., 1758 larvae & $\begin{array}{l}\text { OY, YS (Sv, } \\
\text { ELv) }\end{array}$ & Myodes glareolus & Liver & Euryxenous \\
\hline 9 & Hydatigera taeniaeformis (Batsch 1786) s.l. larvae & OY & Sylvaemus flavicollis & Liver & Euryxenous \\
\hline \multicolumn{6}{|c|}{ Family Mesocestoididae } \\
\hline 10 & Mesocestoides sp. Vaillant, 1863 larvae & YS (Sv) & Myodes glareolus & Abdominal cavity & Euryxenous \\
\hline \multicolumn{6}{|c|}{ Nematoda } \\
\hline \multicolumn{6}{|c|}{ Family Capillariidae } \\
\hline 11 & Pterothominx sadovskoi Morozov, 1956 & $\mathrm{LnV}$ & Myodes glareolus & Small intestine & Euryxenous \\
\hline \multicolumn{6}{|c|}{ Family Trichuridae } \\
\hline 12 & Trichuris muris (Schrank, 1788) & $\mathrm{OY}$ & Sylvaemus flavicollis & Cecum & Euryxenous \\
\hline \multicolumn{6}{|c|}{ Family Metastrongylidae } \\
\hline 13 & Metastrongylidae spp. Molin, 1861 & OY & Myodes glareolus & Lungs & Euryxenous \\
\hline \multicolumn{6}{|c|}{ Family Heligmosomidae } \\
\hline 14 & Heligmosomoides laevis Dujardin, 1845 & OY & Microtus arvalis & Small intestine & Stenoxenous \\
\hline 15 & Heligmosomoides polygyrus Dujardin, 1845 & $\begin{array}{l}\text { LnV, OY, YS } \\
\text { (Sv, ELv) }\end{array}$ & Sylvaemus flavicollis, Sylvaemus uralensis & Small intestine & Stenoxenous \\
\hline \multicolumn{6}{|c|}{ Family Oxyuridae } \\
\hline 16 & Syphacia nigeriana Baylis, 1928 & OY & Microtus arvalis & Cecum & Stenoxenous \\
\hline 17 & Syphacia petrusewiczi Bernard, 1966 & LnV & Myodes glareolus & Cecum & Oioxenous \\
\hline 18 & Syphacia stroma Linstow, 1884 & $\begin{array}{l}\text { LnV, OY, YS } \\
\text { (Sv, ELv) }\end{array}$ & Sylvaemus flavicollis & Small intestine & Stenoxenous \\
\hline 19 & Syphacia sp. Seurat, 1916 & $\begin{array}{l}\text { LnV, OY, YS } \\
(\text { Sv, ELv) }\end{array}$ & $\begin{array}{l}\text { Myodes glareolus, Microtus arvalis, } \\
\text { Sylvaemus flavicollis, Sylvaemus uralensis }\end{array}$ & Cecum & - \\
\hline \multicolumn{6}{|c|}{ Family Spirocercidae } \\
\hline 20 & Mastophorus muris Gmelin, 1790 & LnV, OY & Myodes glareolus & Stomach & Euryxenous \\
\hline
\end{tabular}

Note: Sites of the Belogorye State Nature Reserve: LnV - «Les na Vorskle», OY - «Ostrasyevy Yary», YS (Sv, ELv) - «Yamskaya Step’» (Sury valley, Eremkin Log valley). Specificity of helminthes: oioxenous parasite - highly specific to a host species; stenoxenous parasite - specific at the level of host genus; oligoxenous parasite - specific at the level of a host family; euryxenous parasite - infests a broad range of non-related hosts.

The fodder base of micromammals included the food of both plant (seeds, vegetative parts of plants) and animal (Molluska, Myriapoda, Insecta) origin. Cricetidae species fed mainly on herbaceous plants. Muridae preferred cereal crops, but their food spectra also included terrestrial invertebrates (Terekhovich, 1966). The differences in the feeding types and the main food types could affect the invasion of rodents by certain helminth species.

The helminthes were divided into eight groups according to the way of penetration into the host body (Tokobaev, 1976). On the examined sites in the Belogorye State Nature Reserve, there were three groups of helminthes (Table 3). First of them were invasive larvae in the eggs. Infection occurred when the eggs were swallowed ( 8 species). The second group was represented by invasive larvae living freely in terrestrial ecosystems. The infection occurred during ingestion of larvae (for example, together with plant leaves) (2 species). The third group includes invasive larvae localised in the body of terrestrial invertebrates (intermediate hosts). Infection of definitive hosts (small mammals) occurred, once the rodent consumed the intermediate hosts ( 9 species). We did not succeed in referring the representatives of the family Metastrongylidae to any group, because their biology has still not been studied sufficiently. Considering that the helminthes of the first, second (except Myodes glareolus), and the third group were found in all the studied hosts, we assumed that the diet of both Cricetidae and Muridae species included both plant and animal components and thus it was quite similar. 
Table 3. Quantitative indicators and characteristics of helminthes in mouse-like rodents captured in the Belogorye State Nature Reserve (European Russia) in 2016-2017

\begin{tabular}{|c|c|c|c|c|c|c|c|}
\hline № & Helminth taxa & Host & $\begin{array}{c}P P \text { for certain } \\
\text { species of hosts, } \%\end{array}$ & $P P$ total, $\%$ & IIA & $A I$ & $\begin{array}{l}\text { Way of penetration } \\
\text { into the host body }\end{array}$ \\
\hline \multicolumn{8}{|c|}{ Trematoda } \\
\hline 1 & Platynosomum muris & $\begin{array}{l}\text { Myodes glareolus } \\
\text { Sylvaemus flavicollis }\end{array}$ & $\begin{array}{l}1.89 \pm 1.87 \\
5.26 \pm 3.60\end{array}$ & $2.55 \pm 1.45$ & $\begin{array}{l}1-6 \\
1-5\end{array}$ & $\begin{array}{l}0.11 \\
0.16\end{array}$ & LiI* \\
\hline 2 & Dicrocoeliidae spp. & $\begin{array}{l}\text { Myodes glareolus } \\
\text { Sylvaemus flavicollis }\end{array}$ & $\begin{array}{l}1.87 \pm 1.86 \\
2.63 \pm 2.59 \\
\end{array}$ & $1.70 \pm 1.19$ & $\begin{array}{l}0-1 \\
1-3 \\
\end{array}$ & $\begin{array}{l}0.02 \\
0.08\end{array}$ & LiI* \\
\hline \multicolumn{8}{|c|}{ Cestoda } \\
\hline 4 & Paranoplocephala omphalodes & Myodes glareolus & $5.67 \pm 3.18$ & $4.76 \pm 1.96$ & $1-2$ & 0.09 & LiI \\
\hline 5 & Catenotaenia henttoneni & Myodes glareolus & $3.78 \pm 2.62$ & $1.70 \pm 1.19$ & $0-2$ & 0.08 & LiI \\
\hline 6 & Spasskijela lobata & $\begin{array}{l}\text { Sylvaemus flavicollis } \\
\text { Sylvaemus uralensis }\end{array}$ & $\begin{array}{l}7.90 \pm 4.37 \\
6.70 \pm 6.45\end{array}$ & $3.40 \pm 1.67$ & $\begin{array}{l}2-5 \\
0-2\end{array}$ & $\begin{array}{l}0.30 \\
0.13\end{array}$ & LiI \\
\hline 7 & Hymenolepis sp. & $\begin{array}{l}\text { Myodes glareolus } \\
\text { Sylvaemus flavicollis } \\
\text { Sylvaemus uralensis } \\
\text { Apodemus agrarius }\end{array}$ & $\begin{array}{c}3.77 \pm 2.61 \\
36.80 \pm 7.80 \\
6.70 \pm 6.45 \\
100.00\end{array}$ & $17.00 \pm 3.46$ & $\begin{array}{c}1-3 \\
3-129 \\
1-2 \\
20-47\end{array}$ & $\begin{array}{c}0.06 \\
7.26 \\
0.20 \\
33.50\end{array}$ & LiI* \\
\hline 9 & Hydatigera taeniaeformis s.1. larvae & $\begin{array}{l}\text { Microtus arvalis } \\
\text { Sylvaemus flavicollis }\end{array}$ & $\begin{array}{c}10.00 \pm 9.50 \\
1.90 \pm 2.21 \\
\end{array}$ & $0.85 \pm 0.84$ & $\begin{array}{l}0-1 \\
0-1\end{array}$ & $\begin{array}{l}0.10 \\
0.03\end{array}$ & $\mathrm{E}$ \\
\hline 10 & Mesocestoides sp. larvae & $\begin{array}{l}\text { Microtus arvalis } \\
\text { Myodes glareolus } \\
\text { Apodemus agrarius }\end{array}$ & $\begin{aligned} 20.00 & \pm 12.65 \\
1.90 & \pm 1.80 \\
& -\end{aligned}$ & $0.85 \pm 0.84$ & $\begin{array}{l}2-3 \\
0-1 \\
0-1\end{array}$ & $\begin{array}{l}0.50 \\
0.02 \\
0.50\end{array}$ & LiI \\
\hline \multicolumn{8}{|c|}{ Nematoda } \\
\hline 11 & Pterothominx sadovskoi & Myodes glareolus & $11.32 \pm 4.35$ & $5.09 \pm 2.02$ & $1-60$ & 3.92 & $\mathrm{E}$ \\
\hline 12 & Trichuris muris & Sylvaemus flavicollis & $13.16 \pm 5.48$ & $4.24 \pm 1.86$ & $2-9$ & 0.60 & $E$ \\
\hline 13 & Metastrongylidae spp. & Myodes glareolus & $1.89 \pm 1.87$ & $0.85 \pm 0.84$ & $0-12$ & 0.23 & $?$ \\
\hline 14 & Heligmosomoides laevis & Microtus arvalis & $20.00 \pm 12.65$ & $6.80 \pm 2.32$ & $1-6$ & 0.7 & FLL \\
\hline 15 & Heligmosomoides polygyrus & $\begin{array}{l}\text { Sylvaemus flavicollis } \\
\text { Sylvaemus uralensis }\end{array}$ & $\begin{array}{c}55.26 \pm 8.07 \\
46.67 \pm 12.89 \\
\end{array}$ & $14.4 \pm 3.23$ & $\begin{array}{c}1-12 \\
1-6 \\
\end{array}$ & $\begin{array}{c}3.44 \\
0.8 \\
\end{array}$ & FLL \\
\hline 16 & Syphacia nigeriana & Microtus arvalis & $30.00 \pm 14.50$ & $4.70 \pm 1.95$ & $1-4$ & 0.70 & $E$ \\
\hline 17 & Syphacia petrusewiczi & Myodes glareolus & $1.90 \pm 1.80$ & $1.89 \pm 1.25$ & $0-1$ & 0.02 & $E$ \\
\hline 18 & Syphacia stroma & Sylvaemus flavicollis & $23.70 \pm 6.90$ & $17.00 \pm 11.96$ & $2-43$ & 3.90 & $\mathrm{E}$ \\
\hline 20 & Mastophorus muris & Myodes glareolus & $15.09 \pm 4.90$ & $6.78 \pm 2.30$ & $1-8$ & 0.49 & LiI* \\
\hline
\end{tabular}

Note: E - invasive larvae were in the eggs, infection occurred when the eggs were swallowed; FLL - invasive larvae live freely in terrestrial ecosystems, the infection occurred during ingestion of larvae; LiI - invasive larvae were localised in the body of terrestrial invertebrates (intermediate hosts), invasion of definitive hosts (small mammals) occurred when the rodent consumed the intermediate host; asterisk $(*)$ indicates the helminthes that infect the rodents through prey (invertebrates) as a result of active hunting.

Single trematodes occurred only in the studied mouse-like rodents sampled on the site «Yamskaya Step'». Platynosomum muris Stcherbakova, 1942 was found with low abundance $(P P=2.55 \%)$ only in four host specimens. Other species of the family Dicrocoeliidae $(1.7 \%)$ were also recorded in low number. However, they have not been identified at species level. These helminthes were polyhostal. Their life cycle probably included terrestrial mollusks or insects as intermediate hosts, since there were no large water bodies on the sampling site.

Among Cestoda species, we found mature adults $(55 \%)$, for which rodents were the final hosts, as well as larva individuals (45\%), which used rodents as intermediate hosts. Hymenolepis sp. $(P P=17 \%)$ dominated amongst mature adults, followed by Paranoplocephala omphalodes (Hermann, 1783) Lühe, 1910 (4.8\%),
Spasskijela lobata (Baer, 1925) Tenora, 1959 (3.4\%) (subdominant species), Catenotaenia henttoneni Haukisalmi \& Tenora, 1993 (1.7\%), and Anoplocephaloides dentata (Galli-Valerio, 1905), Rausch, 1976 (1.6\%) (secondary species).

Paranoplocephala omphalodes was found in Myodes glareolus, while Microtus arvalis was the main definitive host of this parasite in the neighbouring regions (Kursk region and Voronezh region) (Romashova \& Romashov, 1996; Vlasov et al., 2015). We determined this species according to morphological characters. However, $P$. omphalodes is morphologically similar to some other species. In this case, it is preferable to analyse the nucleotide sequences, since there is no molecular genetic evidence that this parasite infects Myodes glareolus in the Central Russian Upland, nor in the whole of Russia (Vlasenko et al., 2019). 
Taenia sp. (3.4\%) was the dominant cestode species at the larval stages of development. PP of Hydatigera taeniaeformis (Batsch 1786) larvae and Mesocestoides sp. larvae were only $0.85 \%$. As domestic cats (Felis catus Linnaeus, 1758 ) play a considerable role in the $H$. taeniaeformis distribution, this parasite species can occur much more frequently on territories adjacent to Protected Areas.

According to the degree of specificity, euryxenous species prevailed among the registered cestodes (six species, including three at the larval ontogenetic stages). One species was oligoxenous (found in Cricetidae species). Finally, one species was stenoxenous (found only in Sylvaemus uralensis and Apodemus agrari$u s$ ) (Table 2).

Heligmosomoides $(P P=27.1 \%)$ and Syphacia $(P P=35.6 \%)$ were the dominant Nematoda genera, in particular, presented by Heligmosomoides polygyrus Dujardin, 1845 (14.4\%) and Syphacia stroma Linstow, 1884 (17\%). Subdominant species were presented by Mastophorus muris Gmelin, 1790 (6.8\%), Pterothominx sadovskoi Morozov, 1956 (5.1\%), and Trichuris muris (Schrank, 1788) (4.2\%). Syphacia petrusewiczi Bernard, 1966 (1.9\%) was a rare species (Table 3 ).

According to the host specificity, the found nematodes were presented nearly equally by polyhostal (euryxenous) parasites (4 species) with a wide range of potential hosts and genusspecific (stenoxenous) parasites (4 species). One species, Syphacia petrusewiczi, was highly specific for Myodes glareolus (Table 3).

Part of the specimens, designated as $S y$ phacia sp. and similar to Sylvaemus flavicollis, was not identified to the species level, because the helminth specimens were damaged. These species were localised in the upper parts of the small intestine. It is not typical for most Syphacia species, while it is typical for Syphacia stro$m a$. In addition, some morphological traits (e.g., the shape of the cephalic apex, distribution and number of papillae) indicated that these nematodes could belong to $S$. stroma. However, additional genetic analysis is necessary for confident species identification.

Long-term studies of the helminth fauna of mouse-like rodents have been also carried out in regions, adjacent to the Belgorod region (Kursk region (Vlasov et al., 2015; Vlasov, 2016), Voronezh region (Romashov \& Shulyak, 1995; Ro- mashova \& Romashov, 1996; Romashov, 1997; Romashov et al., 2003). However, these investigations concerned only Protected Areas. The comparison of these studies and our results demonstrates that in the Central Chernozem Region of Russia, the helminth fauna comprises in total over 60 species at the mature adult and larval ontogenetic stages of the five species of mouselike rodents. Amongst them there are Trematoda (at least eight and one species in mature adult and larval stages, respectively), Cestoda (at least 11 and nine species in mature adult and larval stages, respectively), Nematoda (at least 26 and two species in mature adult and larval stages, respectively), and Acanthocephala (only one species in the larval ontogenetic stage).

Now, nine species have been recorded for all three mentioned regions, including Anoplocephaloides dentata (Galli-Valerio, 1905), Rausch, 1976, Paranoplocephala omphalodes, Spasskijela lobata, Hydatigera taeniaeformis s.1. (larvae), Trichuris muris, Heligmosomoides polygyrus, Syphacia nigeriana Baylis, 1928, S. petrusewiczi, and S. stroma. Four species (Plagiorchis elegans (Rudolphi, 1802), Catenotaenia matovi Genov, 1971, Heligmosomum costellatum (Dujardin, 1845), and Syphacia agrarian Sharpilo, 1973) were reported in Kursk region and Voronezh region, while they are still not registered in rodents of the Belgorod region. The first of those four species was recorded at the stage of cercaria in mollusks in the Belgorod region. Most likely, the remaining three species may also be found in the Belgorod region in future.

Mesocestoides sp. (larvae), Heligmosomoides laevis Dujardin, 1845 and Mastophorus muris are known in the Belgorod region and Voronezh region. Parasites of the genus Hymenolepis were reported for the Belgorod region (Hymenolepis sp.) and Kursk region (Hymenolepis apodemi Makarikov \& Tkach, 2013, Hymenolepis sp.).

The larvae of trematodes Posterocirrus clethrionomi Andreiko \& Khotenovsky, 1964, Skrjabinoplagiorchis vigisi Petrov \& Merkuscheva, 1963, Psilotrema simillimum (Muhling, 1898), Notocotylus noyeri Joyeux, 1922, Echinostoma miyagawai Ishii, 1932, Echinostoma revolutum (Fröhlich, 1802), and Alaria alata (Goeze, 1782) were recorded only in the Voronezh region. This may be explained by the lack of large water bodies which is necessary to complete the life cycle of trematodes in the Kursk region and Belgorod region. 
Platynosomum muris has currently only been recorded in the Belgorod region, being reported for the first time in the Central Chernozem Region of Russia. Cestodes of genus Catenotaenia are found in all three regions. Of them, $C$. henttoneni is known in Belgorod region and Kursk region, while C. cricetorium Kirschenblatt, 1949 is noted in the Belgorod region.

Among cestodes, the mature adults of Paranoplocephala gracilis Tenora \& Murai, 1980 and larvae of Paruterina candelabraria (Goeze, 1782), Taenia crassiceps (Zeder, 1800), T. martis (Zeder, 1803), T. polyacantha Leuckart, 1856, and Versteria mustelae (Gmelin, 1790) are known only in the Voronezh region. Only in the Kursk region, Rodentolepis straminea (Goeze, 1782) and unidentified taxa of families Anoplocephalidae and Paruterinidae are noted.

Nematodes of the genus Heligmosomoides are known in a large number from all three regions. However, H. polygyrus is predominated among them. Heligmosomoides laevis is a specific parasite of the genus Microtus. It less commonly occurrs and is known only in the Voronezh region and Belgorod region. Noteworthy, H. glareoli Baylis, 1928, a widespread parasite of Myodes glareolus, has not been found in the Belogorye State Nature Reserve, although this species is the dominant species in the Voronezh region. Finally, H. mixtum is reported only in the Voronezh region.

The nematodes Capillaria hepatica Bancroft, 1893, C. murissylvatici Dieseng, 1851, Eucoleus bacillatus (Eberth, 1863), Trichinella native Britov \& Boev, 1972, Strongyloides papillosus (Wedl, 1856), Ganguleterakis spumosa (Schneider, 1866), Aspiculuris dinniki Schulz, 1927, A. tetraptera (Nitzsch, 1821), Syphacia obvelata (Rudolphi, 1802), Rictularia proni Seurat, 1915, Boreostrongvlus minutus , Syngamus sp., Physocephalus sexalatus (Molin, 1860) (larvae), and Spirocerca lupi (Rudolphi, 1809) (larvae) are known only in the Voronezh region. Trichocephalus arvicolae and Syphacia frederici Roman, 1945 were reported only in the Kuresk region.

The nematode Pterothominx sadovskoi is known only from the Belgorod region. In the present study, this species is noted for the first time in the Central Chernozem Region of Russia. Only one species of Acanthocephala, Macracanthorhynchus catulinus Kostylew, 1927 (larvae), was registered in mouse-like rodents in the Voronezh region. Its presence is associated with a specific intermediate host, the beetle Elenephorus sp.

\section{Conclusions}

In the present study, five species of mouselike rodents (Myodes glareolus, Microtus arvalis, Sylvaemus flavicollis, Sylvaemus uralensis, and $A$. agrarius) were registered in 2016-2017 at three clusters in the Belogorye State Nature Reserve («Les na Vorskle», «Ostrasyevy Yary», and "Yamskaya Step"»). Twenty helminth species were found. Of them, ten species belong to Nematoda, and ten species to Plathelminthes, including eight Cestoda species and two Trematoda species. In Cestoda, we found both mature adults (for which the rodents were definitive hosts) and larvae (for which the rodents were intermediate hosts). In the examined mammals, the parasite prevalence was $72 \%$. We recorded parasites in $91 \%$ of the Muridae specimens and only in $55.6 \%$ of the Cricetidae specimens.

According to the host specificity, euryxenous species prevailed in flatworms. The nematodes were represented by polyhostal and host-specific species in almost equal proportions. Syphacia petrusewiczi, a highly specific parasite for Myodes glareolus, was also found.

We found dominant species characterised by maximum parasite prevalence, invasion intensity amplitude, and abundance index. There were Hymenolepis sp. $(P P=17 \%$, $1<I I A<129)$ amongst Plathelminthes, the species of Syphacia $(P P=35.6 \%)$ and Heligmosomoides $(P P=27.1 \%)$ amongst Nematoda, in particular, S. stroma (17\%) and H. polygyrus (14.4\%). The other helminth species registered within the present study were either secondary $(2 \%<P P<14 \%)$ or rare $(P P<2 \%)$.

Two species, Platynosomum muris (Trematoda, Dicrocoeliidae) and Pterothominx sadovskoi (Nematoda, Capillariidae), were reported for the first time for the helminth fauna of the Central Chernozem Region of Russia.

\section{References}

Anikanova V.S., Bugmyrin S.V., Ieshko E.P. 2007. Methods for collecting and studying helminthes of small mammals. Petrozavodsk: Karelian Research Center of RAS. 145 p. [In Russian]

Caira J.N., Jensen K., Barbeau E. (Eds). 2020. Global Cestode Database. Available from www.tapewormdb.uconn.edu 
Dobson A., Lafferty K.D., Kuris A.M., Hechinger R.F., Jetz W. 2008. Homage to Linnaeus: how many parasites? How many hosts? Proceedings of the $\mathrm{Na}$ tional Academy of Sciences of the United States of America 105(Suppl. 1): 11482-11489. DOI: 10.1073/ pnas.0803232105

Gromov I.M., Erbaeva M.A. 1995. Mammals of the fauna of Russia and adjacent territories. Lagomorphsand rodents. Saint-Petersburg: Zoological Institute RAS. 522 p. [In Russian]

Hudson P.J., Dobson A.P., Lafferty K.D. 2006. Is a healthy ecosystem one that is rich in parasites? Trends in Ecology and Evolution 21(7): 381-385. DOI: 10.1016/j.tree.2006.04.007

Karaseva E.V., Telitsina A.Yu. 1996. Methods for the study of rodents in the field: counts and tagging. Moscow: Nauka. 227 p. [In Russian]

Orlova M.V., Orlov O.L. 2019. Conservation of animals' parasite species: problems and prospects. Nature Conservation Research 4(1): 1-21. DOI: 10.24189/ ncr.2019.011 [In Russian]

Pavlinov I.Ya., Lissovsky A.A. (Eds). 2012. The Mammals of Russia: A Taxonomic and Geographic Reference. Moscow: KMK Scientific Press Ltd. 604 p. [In Russian]

Poulin R., Morand S. 2000. The diversity of parasites. Quarterly Review of Biology 75(3): 277-293. DOI: 10.1086/393500

Romashov B.V. 1997. Helminthes of mouse-like rodents in the Usmansky pine forest. Proceedings of $\mathrm{Vo}$ ronezh State Nature Biosphere Reserve. 23: 186206. [In Russian]

Romashov B.V., Shulyak A.V. 1995. Helminthes of rodents at the biological station of the Voronezh State University. Proceedings of the biological educational-scientific centre of the Voronezh State University «Venevitinovo» 6: 101-106. [In Russian]

Romashov B.V., Khitsova L.N., Trufanova E.I., Romashova N.B. 2003. Methodics of helminthological studies of vertebrates. Voronezh: Voronezh State University. 35 p. [In Russian]

Romashova N.B. 2004. Ecology and biodiversity of helminthes of mouse-like rodents in the conditions of island forests of the Central Chernozem Region. $\mathrm{PhD}$ Thesis. Voronezh. 113 p. [In Russian]

Romashova N.B., Romashov B.V. 1996. Helminthes of mouse-like rodents of the Voronezh State Nature Reserve. In: Fauna of the Central Chernozem Region and the formation of ecological culture. Lipetsk. P. 51-52. [In Russian]

Ryzhikov K.M. (Eds). 1978. Determinant of the helminthes in rodents of the USSR fauna. Cestodes and trematodes. Moscow: Nauka. 232 p. [In Russian]
Ryzhikov K.M. (Eds). 1979. Determinant of the helminthes in rodents of the USSR fauna. Nematodes and Acanthocephala. Moscow: Nauka. 272 p. [In Russian]

Shchekalo M.V. 2017. Population and abundance of small mammals in ravine oak forests of the upper Pososkolye region. In: Nature of Belgorod region and its protection. Gubkin. P. 5. [In Russian]

Sheykina Z.V., Zhigileva O.N. 2018. Helminthes of shrews (Soricidae) in the "Malaya Sosva» Nature Reserve (Russia). Nature Conservation Research 3(3): 28-36. DOI: 10.24189/ncr.2018.019 [In Russian]

Skryabin K.I., Shikhobalova N.P., Ladogovskaya E.A. 1961. Oxyurates of animals and humans. Vol. 10(2). Moscow: AS USSR. 497 p. [In Russian]

Souza J.G., Simoes R.O., Thiengo S.A., Lima W.S., Mota E.M., Rodrigues-Sylva R., Lanfredi R.M., Maldonado A.Jr. 2009. A New Metastrongilid Species (Nematoda: Metastrongylidae): A Lungworm From Akodon Montensis (Rodentia: Sigmodontinae) in Brazil. Journal of Parasitology 95(6): 1507-1511. DOI: 10.1645/GE-2013.1

Summers K., McKeon S., Sellars J., Keusenkothen M., Morris J., Gloeckner D., Pressley C., Price B., Snow H. 2003. Parasitic exploitation as an engine of diversity. Biological Reviews 78(4): 639-675. DOI: 10.1017/S146479310300616X

Terekhovich V.F. 1966. Ecology of the Bank vole and Yellow-necked field mouse. PhD Thesis Abstract. Minsk. 22 p. [In Russian]

Tokobaev M.M. 1976. Helminthes of wild mammals in Central Asia. The experience of ecological-geographical analysis. Frunze: Ilim. 177 p. [In Russian]

Vlasenko P., Abramov S., Bugmyrin S., Dupal T., Fomenko N., Gromov A., Zakharov E., Ilyashenko V., Kabdolov Zh., Tikunov A., Vlasov E., Krivopalov A. 2019. Geographical distribution and hosts of the cestode Paranoplocephala omphalodes (Hermann, 1783 ) Lühe, 1910 in Russia and adjacent territories. Parasitology Research 118(12): 3543-3548. DOI: 10.1007/s00436-019-06462-z

Vlasov A.A. 1996. Population of small mammals of Protected Areas in the central forest-steppe zone. $\mathrm{PhD}$ Thesis Abstract. Ekaterinburg. 19 p. [In Russian]

Vlasov E.A. 2016. Helminthes of wild mammals in the Central Chernozem State Nature Reserve (fauna, ecology, pathogenic value). $\mathrm{PhD}$ Thesis. Kursk. 167 p. [In Russian]

Vlasov E.A., Malisheva N.S., Krivopalov A.V. 2015. Helminth fauna of myomorph rodents (Rodentia, Myomorpha) in the Central Chernozem State Nature Reserve. Russian Parasitological Journal 4: 24-33. DOI: $10.737 / 16656$ 


\title{
ПАРАЗИТИЧЕСКИЕ ЧЕРВИ МЫШЕОБРАЗНЫХ ГРЫЗУНОВ ГОСУДАРСТВЕННОГО ПРИРОДНОГО ЗАПОВЕДНИКА «БЕЛОГОРЬЕ» (РОССИЯ)
}

\author{
М. И. Кононова, Ю. А. Присный
}
Белгородский государственный национальный исследовательский университет, Россия e-mail: margosha.ki@yandex.ru,prisniy_y@bsu.edu.ru

Исследования проводились в 2016-2017 гг. на трех участках Белогорского государственного природного заповедника (Россия), расположенных в пределах лесостепной зоны: 1) «Лес на Ворскле» (нагорная дубрава); 2) «Острасьевы яры» (байрачная дубрава, разнотравно-луговая степь); 3 ) «Ямская степь» (балка Суры - кустарниковые заросли, разнотравно-луговая степь; Еремкин лог - нагорная дубрава, разнотравно-луговая степь). Мелкие млекопитающие отлавливались с помощью ловушекдавилок, выставлявшихся в линии по 50 шт. или 100 шт. Дополнительно использовались одиночные давилки и ловчие канавки с конусами (средняя длина 30 м). Среди пойманных грызунов (118 особей) было зарегистрировало пять видов: Myodes glareolus, Microtus arvalis, Sylvaemus flavicollis, Sylvaemus uralensis, Apodemus agrarius. Общая экстенсивность инвазии грызунов составила $72 \%$. При этом среди мышей зараженными оказались 91\%, а зараженность полевок была почти в два раза меньше (55.6\%). Отмечено 20 видов гельминтов, относящихся к трем классам, шести отрядам и 12 семействам. Среди трематод были обнаружены только эвриксенные виды. Среди цестод преобладали эвриксенные виды. Среди нематод эвриксенные и стеноксенные виды присутствовали в равном соотношении. В качестве доминирующих видов, характеризующихся максимальными значениями экстенсивности инвазии (ЭИ) среди плоских червей были отмечены Hymenolepis sp. (17\%), среди нематод - представители родов Syphacia (35.6\%) и Heligmosomoides (27.1\%), в частности S. stroma $(17 \%)$ и H. polygyrus (14.4\%). Остальные виды обнаруженных гельминтов отнесены к малочисленным $(2 \%<$ ЭИ $<14 \%)$ либо к редким (ЭИ $<2 \%)$. Впервые для территории Центрально-Черноземного региона приводятся два вида гельминтов: Platynosomum muris (Trematoda, Dicrocoeliidae), Pterothominx sadovskoi (Nematoda, Capillariidae).

Ключевые слова: Белгородская область, гельминты, микромаммалии, мыши, нематоды, паразиты, полевки, трематоды, цестоды 